\title{
Hubungan Peran Pembimbing Akademik dengan Prestasi Belajar
}

\author{
Dina Martha Fitri, Nurhidayah \\ Program Studi D-IV Bidan Pendidik STIKes Mitra RIA Husada \\ Jl. Karya Bhakti No.3 Cibubur, Jakarta Timur, 13720, Indonesia \\ Email : marthadina@ymail.com, nurhidayah.kila@gmail.com
}

\begin{abstract}
ABSTRAK
Tujuan penelitian ini yaitu untuk diketahuinya hubungan peran pembimbing akademik dengan prestasi belajar. Metode penelitian menggunakan desain penelitian kuantitatif dengan pendekatan cross sectional. Dengan populasi mahasiswa D-III Kebidanan tingkat II dan III. Dengan jumlah sampel 85 orang. Data yang dipakai adalah data primer menggunakan kuisoner yang di uji menggunakan uji validitas dan uji reliabilitas. Diolah dan dianalisis menggunakan Chi Square.

Hasil penelitian didapatkan bahwa hasil belajar yang memuaskan yaitu sebanyak 78 (91,7\%). Dan terdapat $66(77,6 \%)$ responden mengatakan bahwa peran dosen pembimbing akademik aktif. Hasil uji staistik chi-square di dapatkan nilai $\mathrm{P}$ Value sebesar 0,005 dengan nilai $a$ sebesar 0,05 artinya

$P$ Value $<a$. Hal ini menunjukan bahwa Ha di terima dengan kesimpulan bahwa ada hubungan yang

bermakna antara peran pembimbing akademik dengan prestasi belajar responden. Kesimpulan pada penelitian ini adalah Mayoritas mahasiwa D-III Kebidanan Tingkat II dan III memiliki prestasi belajar yang memuaskan dan memiliki dosen pembimbing akademik yang berperan aktif. Sehingga di sarankan untuk meningkatkan peran aktif sebagai motivator pada mahasiswa.
\end{abstract}

\section{Kata Kunci : Peran Pembimbing Akademik, Prestasi Belajar}

\section{PENDAHULUAN}

Berdasarkan Survey United Nations Educational, Scientific and Cultural Organization (UNESCO) terhadap kualitas pendidikan di negara-negara berkembang di Asia Pasific, indonesia menempati peringkat 10 dari 14 negara, sedangkan untuk kualitas para guru,kualitasnya berada pada level 14 dari 24 negara berkembang. Negara indonesia sebagai negara berkembang masih di hadapkan pada berbagai masalah pendidikan yang terutama berkaitan dengan kulitas dan efisiensi pendidikan. Selain hal tersebut, permasalahan yang di hadapi bangsa indonesia adalah rendahnya mutu pendidikan. Mutu pendidikan suatu bangsa dapat di katakan berkualitas apabila pendidikan yang di laksanakan dapat memberikan lulusannya kemampuan, pengetahuan dan keterampilan yang berguna untuk melanjutkan ke tingkat pendidikan yang lebih tinggi maupun untuk memasuki dunia kerja.

Prestasi belajar mahasiswa perguruan tinggi merupakan salah satu persyaratan yang di perhitungkan untuk mendapatkan pekerjaan. Hal ini sudah cukup lama menjadi perbincangan oleh beberapa pakar pendidikan dan termasuk juga oleh para pengelola pendidikan perguruan tinggi. Slameto (2010), mengatakan, untuk mengetahui hasil belajar yang di capai siswa di adakan penilaian. Penilaian ini dapat di adakan setelah siswa menyelesaikan progam pembelajaran dalam waktu tertentu, misalnya di lihat dari indek prestasi mahasiwa tersebut.

Ada dua faktor yang mempengaruhi hasil prestasi mahasiswa yaitu faktor internal (dari dalam diri mahasiswa), dan faktor eksternal (dari luar mahasiswa). Faktor internal antara lain : motivasi belajar, semangat belajar, kecerdasan dan lain sebagainya. Sedangkan faktor dari luar antara lain: lingkungan keluarga, tempat belajar (lingkungan sekolah) dan lingkungan masyarakat (Sigit, 2012). Guru, dosen atau pengajar merupakan salah satu faktor yang mempengaruhi prestasi belajar. Prestasi belajar di pengaruhi oleh motivasi, sedangkan guru, dosen atau pengajar merupakan faktor eksternal yang mempengaruhi motivasi belajar. Dalam proses belajar pembelajaran tanggung jawab pencapaian tujuan belajar selain terletak pada mahasiswa juga pada pembimbing akademik. Peran pembimbing sebagai motivator merupakan salah satu aspek yang sangat penting untuk mencapai keberhasilan dalam pembelajaran, dengan demikian mahasiswa termotivasi untuk melaksanakan dan mencapai tujuan pembelajaran selama menempuh pendidikan. Membantu mahasiwa agar dapat 
mengembangkan sikap dan kebiasaan belajar yang baik.Sebagai deskripsi awal pembimbing Akademik Program DIII Kebidanan STIKes Mitra R1A Husada di bentuk dengan tujuan utama memberikan bantuan secara sistematis dan insentif kepada mahasiswa untuk lebih mengenal, memahami dan mengembangkan diri, akademik, sosial dan karir di masa depan secara optimal. Kegiatan yang di jalankan meliputi pelayanan-pelayanan pendataan mahasiswa /pihak-pihak lainnya, sehingga tercipta suasana akademik yang kondusif dalam mencapai visi-misi STIKes Mitra R1A Husada. Tujuan akhir dari program layanan yang di berikan oleh pembimbing Akademik adalah berkembangannya spiritual. Yang bertugas dalam lembaga ini adalah dosen/tenaga yang di unjuk/ di angkat dengan tugas-tugas yang sudah dijelaskan.Jumlah mahasiswa program DIII Kebidanan Tingkat II dan III yaitu berjumlah 85 mahasiswa dimana jumlah mahasiswa tingkat II Sebanyak 32 orang dan jumlah mahasiswa tingkat III yaitu sebanyak 53 orang. Berdasarkan studi pendahuluan yang di lakukan pada mahasiswa tingkat II dan tingkat III program studi DIII Kebidanan STIKes Mitra R1A Husada. 7 dari 10 orang mahasiswa mengatakan bahwa dosen PA tidak berperan aktif dalam meningkatkan motivasi belajar mahasiswa, di karenakan jadwal bimbingan akademik yang tidak di lakukan secara rutin . Dari data yang di dapatkan dari bagian evaluasi jurusan kebidanan di peroleh hasil prestasi belajar pada tingkat II tahun ajaran 2016/2017 yaitu sebanyak 44\% mengalami penururnan prestasi belajar, dan $66 \%$ mengalami peningkatan prestasi belajar.

Salah satu yang menyebabkan prestasi belajar mahasiswa menurun yaitu karena kurangnya motivasi untuk belajar, motivasi belajar merupakan salah satu faktor internal yang di miliki setiap individu . Dan motivasi belajar dapat di pengaruhi oleh guru, dosen atau pengjar khususnya dosen pembimbing Akademik. Di STIKes Mitra R1A Husada belum adanya penelitian tentang hubungan peran pembimbing Akademik dengan prestasi belajar mahasiswa.

\section{METODE PENELITIAN}

Desain penelitian ini merupakan penelitian kuantitatif dengan pendekatan cross sectional adalah dimana data yang menyangkut variabel bebas atau resiko dan variabel terkait atau akibat akan di kumpulkan dan di ukur dalam waktu yang bersamaan ketika penelitian ini di lakukan (Notoatmodjo, 2012). Penelitian dilakukan di STIKes Mitra R1A Husada, Jakarta Timur. Penelitian ini d laksanakan dari mulai penyusunan proposal Desember 2017 sampai dengan Juli 2018. Teknik sampel yang di gunakan dalam penelitian ini yaitu total sampling yaitu menggunakan seluruh jumlah populasi mahasiswa D-III Kebidanan STIKes Mitra RIA Husada tingkat II dan II berjumlah sebanyak 85 orang.

Alat ukur yang di gunakan dalam penelitian ini adalah dokumentasi (KHS) dan kuisoner . Kuisoner tersebut berupa peran pembimbing Akademik. Untuk data primer di ukur menggunakan kuisoner yang telah di uji validitas dan reabilitas. Analisis data pada penelitian ini adalah analisa univariate dan bivariat dengan uji statistic Chi Square

\section{HASIL PENELITIAN}

Analisis univariat adalah analisi yang digunakan untuk satu variabel atau pervariabel, catatan: dalam pengertian tertentu analisis deskriptif menjadi sama dengan analisis univariat (Sujarweni, 2015).

Tabel

Hasil Belajar dari 85 Mahasiswa D-III Kebidanan Tingkat II dan III STIKES Mitra RIA Husada Tahun 2018.

\begin{tabular}{clcc}
\hline No & Variabel & f & $\%$ \\
\hline 1 & Prestasi Belajar & & \\
& Tidak Memuaskan & 7 & $8,3 \%$ \\
& Memuaskan & 78 & $91,7 \%$ \\
\hline
\end{tabular}




\begin{tabular}{llll}
\hline 2 & Peran PA & & \\
Tidak Aktif & 19 & $22,4 \%$ \\
& Aktif & 66 & $77,6 \%$
\end{tabular}

Tabel diatas menunjukan bahwa hasil belajar dari 85 mahasiswa untuk prestasi yang terbanyak adalah prestasi memuaskan yaitu sebanyak 78 (91,7\%), Sedangkan peran pembimbing akademik yang terbanyak adalah peran pembimbing akademik aktif sebanyak $66(77,6 \%)$.

\section{Analisis Bivariat}

Analisis bivariat yang di lakukan terhadap variabel yang di duga berhubungan atau berkolerasi. Hubungan variabel independen terhadap variabel dependen terdapat pada tabel di bawah ini:

Tabel

Analisis Bivariat Hubungan Peran Pembimbing Akademik Terhadap Prestasi Belajar Mahasiswa D-III Kebidanan STIKES Mitra RIA Husada Tingkt II dan III Tahun 2018

\begin{tabular}{|c|c|c|c|c|c|c|c|}
\hline \multicolumn{7}{|c|}{ Peran Dosen Pembimbing Prestasi Belajar Mahasiswa } & \multirow{3}{*}{$\begin{array}{l}\text { OR }(95 \%) \\
\text { CI }\end{array}$} \\
\hline Akademik & \multicolumn{2}{|c|}{ Tidak memuaskan } & \multicolumn{2}{|c|}{ Memuaskan } & \multirow[t]{2}{*}{ Total } & \multirow[t]{2}{*}{$p$} & \\
\hline & $\mathrm{n}$ & $\%$ & $\mathrm{n}$ & $\%$ & & & \\
\hline Tidak aktif & 5 & $26,3 \%$ & 14 & $73,7 \%$ & 19 & 0,005 & 11,425 \\
\hline Aktif & 2 & $3,0 \%$ & 64 & $97,0 \%$ & 66 & & \\
\hline Total & 7 & $8,2 \%$ & 78 & $91,8 \%$ & 85 & & \\
\hline
\end{tabular}

Tabel diatas menunjukan presentase peran dosen tidak aktif sebanyak 19 responden dengan $14(73,7 \%)$ pretasi memuaskan dan $5(26,3 \%)$ tidak memuaskan. Dan terdapat 66 mahasiswa yang mengatakan peran dosen aktif dengan $64(97,0 \%)$ prestasi memuaskan dan $2(3,0 \%)$ tidak memuaskan.

Hasil uji staistik chi-square di dapatkan nilai $P$ Value sebesar 0,005 dengan nilai a sebesar 0,05 artinya $P$ Value $<a$. Hal ini menunjukan bahwa Ha di terima dengan kesimpulan bahwa ada hubungan yang bermakna antara peran pembimbing akademik dengan prestasi belajar responden. Nilai OR di peroleh 11,429 yang artinya kelompok responden dengan peran dosen tidak aktif dengan hasil belajar tidak memuaskan memiliki peluang atau resiko 11 kali di bandingkan dengan kelompok responden dengan peran dosen aktif dengan hasil belajar tidak memuaskan. Dengan rentang Confidience Interval 2,008-6,035 pada derajat kepercayaan $95 \%$.

\section{PEMBAHASAN}

\section{Prestasi Belajar Mahasiswa D-III Kebidanan tingkat II Dan III STIKES Mitra RIA Husada Tahun 2108.}

Berdasarkan analisis univariat didapatkan bahwa mayoritas mahasiswa D-III Kebidanan tingkat II dan III STIKES Mitra RIA Husada tahun 2018 memperoleh prestasi belajar memuaskan. Hasil penelitian ini sesuai dengan teori yang menyatakan bahwa prestasi belajar 
merupakan bentuk rumusan akhir yang di berikan dosen terkait dengan kemajuan atau prestasi belajar mahasiswa selama waktu tertentu (Kamila, 2013). Hasil penelitian ini sesuai dengan teori yang di kemukakan oleh Moh.Surya yaitu prestasi belajar adalah hasil belajar atau perubahan tingkah laku menyangkut ilmu pengetahuan, keterampilan, dan sikap setelah melalui proses tertentu, sebagai hasil pengalaman individu dalam interaksi dan lingkungannya (Purwanto, 2014).

Sesuai dengan penelitian Patmasari (2015), yang menunjukan bahwa mayoritas mahasiswa memperoleh prestasi belajar belajar memuaskan sebanyak 57,8\% .Sesuai dengan penelitian Cholida, yang menunjukan bahwa mayoritas mahasiswa memperoleh prestasi belajar belajar memuaskan sebanyak (71\%). Sesuai dengan hasil penelitian Kriscilia Molly (2014) prestasi belajar mahasiswa dengan 75 responden di dapatkan bahwa prestasi belajar yang di capai mahasiswa adalah prestasi belajar baik sebesar $60,7 \%$.

Asusmsi peneliti tentang prestasi belajar, mahasiswa perlu diukur atau dinilai untuk mengetahui sejauh mana tingkat keberhasilan yang dicapai mahasiswa dalam proses belajar. Pengukuran ini dilakukan selain untuk memotivasi mahasiswa, juga sebagai dasar bagi pendidik untuk menentukan langkah selanjutnya dalam proses belajar.

\section{Peran Pembimbing Akademik}

Berdasarkan analisis univariat di dapatkan bahwa mayoritas mahasiswa D-III Kebidanan tingkat II dan III STIKES Mitra RIA Husada tahun 2018 memperoleh peran pembimbing akademik aktif. Hal ini sesuai dengan teori yang menyatakan Pembimbing akademik adalah staf pengajar tetap suatu perguruan tinggi yang paling tepat untuk menjadi sumber bantuan nasehat akademik agar para mahasiswa dapat menyelesaikan tugasnya sebagai mahasiswa. tujuan bimbingan adalah membantu mahasiswa mengembangkan potensinya sehingga memperoleh hasil yang optimal dan dapat menyelesaikan studinya dengan waktu yang di tentukan; tugas dan kebijaksanaan, bebas dsri paksaan atau suruhan dan di maksudkan untuk membawa ke pengaruh diri (Silitonga, 2010).

Hal ini sesuai dengan teori yang di kemukakan oleh Hendro Saputro (2010) mengemukakan bahwa pembimbing akademik adalah tenaga pengajar tetap yang ditunjuk dan diserahi tugas membimbing mahasiswa; tujuan bimbingan adalah membantu mahasiswa mengembangkan potensinya sehingga memperoleh hasil yang optimal dan dapat menyelesaikan studinya dengan waktu yang ditentukan; tugas dan kebijaksanaan, bebas dari paksaan atau suruhan, dan dimaksudkan untuk membawa ke pengarahan diri. Sesuai dengan hasil penelitian yang di lakuakan oleh Patmawati (2015) bahwa mayoritas peran dosen pembimbing akademik yang aktif sebanyak $84,4 \%$. Sesuai dengan hasil penelitian yang dilakukan Yarni (2008), mayoritas peran dosen pembimbing yang aktif sebanyak $94,7 \%$. Sesuai dengan hasil penelitian yang di lakuakn Dewi Amalia, mayoritas peran dosen pembimbing yang aktif sebanyak 90,5\%.

Menurut asusmi peneliti peran pembimbing akademik merupakan hal yang sangat di butuhkan oleh mahasiswa dalam proses pembelajaran. Karena mahasiswa dapat Memberikan gambaran tentang kemungkinan, alternatif dan peluang yang dapat di pilih mahasiswa dalam merencanakan kegiatan studi serta konsekuensinya, khususnya tentang beban studi suatu semester tertentu dan mata kuliah yang akan di tempuhnya.

\section{Hubungan Peran Dosen Pembimbing Akademik Dengan Prestasi Belajar Mahasiswa di STIKES Mitra RIA Husada}

Berdasarkan hasil analisis bivariat ada hubungan antara peran dosen pembimbing akademik dengan prestasi belajar mahasiswa. Hal ini di buktikan dengan adanya hubungan antar kategori dimana sebagian besar prestasi belajar memuaskan dari mahasiswa yang memiliki peran dosen pembimbing akademik yang aktif. 
Hal ini sesuai dengan teori yang menyatakan bahwa dosen pembimbing akademik memiliki peran positif dan mempunyai andil yang besar dalam menentukan prestasi belajar mahasiswa. Pencapaian kesuksesan dalam belajar dipengaruhi oleh berbagai hal antara lain faktor internal dan eksternal. Faktor internal adalah yang terdapat pada diri seseorang termasuk kondisi fisiologis secara umum, kondisi panca indera, minat intelegensi/kecerdasan, bakat, dan motivasi sedangkan faktor eksternal yang terdapat di luar diri seseorang meliputi faktor lingkungan (Silitonga,2010).

Hal ini sesuai dengan teori dosen pembimbing akademik bertugas memberikan, membantu, memilih, dan menentukan program belajar, kegiatan kokurikuler dan ekstrakurikuler yang akan diikutinya dan juga monitor perkembangan kemajuan studi mahasiswa dan apabila perlu membangkitkan dan mengembangkan motivasi belajarnya (Syarifuddin, 2012).

Hal ini sesuai dengan teori bahwa, peran fasilitator dalam suatu pembelajaran adalah memandu proses pembelajaran untuk mencapai tujuan pembelajaran, dan bukan memberikan informasi tentang isi atau materi pembelajaran. Agar aktivitas "perjalanan" kelompok peserta untuk mencapai tujuan pembelajaran berlangsung dengan baik maka lingkungan, baik lingkungan fisik maupun lingkungan sosial haruslah menyenangkan. Dalam mengatur lingkungan fisik ruang belajar fasilitator dapat meminta bantuan dan berkerjasama dengan penyelenggara pelatihan, namun lingkungan sosial sangat ditentukan oleh kemampuan individu fasilitator (Nugroho,2014). Sesuai hasil penelitian Patmasari (2015) analisa hubungan antara peran dosen PA dengan prestasi belajar mahasiswa. Hal ini berarti ada hubungan yang bermakna secara statistik antara peran dosen PA dengan prestasi belajar mahasiswa.

Menurut asumsi peneliti hubungan peran pembimbing akademik dan prestasi belajar merupakan hal yang saling berhubungan karena pemberian Bimbingan dan Konseling adalah salah satu bentuk layanan yang bersifat pendekatan pribadi dan kelompok. Dalam mengembangkan self control pada siswa, diharapkan mampu membantu proses mengatasi masalah-masalah siswa yang berkaitan dengan lemahnya selfcontrol sehingga membantu untuk berkembang kearah yang lebih baik dan membantu tercapainya tujuan belajar.

\section{SIMPULAN}

Berdasarkan hasil penelitian dan pembahasan yang peneliti lakukan pada mahasiswa D-III Kebidanan tingkat II dan III STIKES Mitra RIA Husada tahun 2018, maka dapat disimpulkan sebagai berikut :

1. Mayoritas mahasiwa D-III Kebidanan Tingkat II dan III STIKES Mitra RIA Husada memiliki prestasi belajar yang memuaskan dan peran pembimbing Akademik yang aktif.

2. Ada hubungan peran pembimbung akademik dengan prestasi belajar mahasiswa D-III Kebidanan tingkat II dan III STIKES Mitra RIA Husada tahun 2018. 


\section{Referensi}

Ginting. (2014). Kiat Belajar di Perguruan Tinggi. Jakarta: Grasindo.

Kamila. (2013). Faktor-faktor yang memepengaruhi prestasi belajar. Laporan Penelitian Mandiri.

Notoatmodjo S. (2012). Metodologi Penelitian Kesehatan. Jakarta: Rineka Cipta.

Silitonga. (2014) 7 Langkah Dahsyat Menjadi Pembelajaran Hebat. Jakarta: Salemba Medika.

Syarifuddin A.(2012). Peranan Dosen Wali Bagi Mahasiswa. Jakarta: Salemba Medika

Slameto. (2010). Belajar dan Faktor-Faktor Yang Mempengaruhinya. Jakarta: Rineka Cipta.

Sigit. (2012). Prestasi Belajar dan Kompetensi Guru. Jakarta : Trans Info Media.

Sujarweni. (2015) SPSS Penelitian. Jakarta : Trans Info Media.

Purwanto. (2014). Psikologi Pendidikan. Jakarta: TIM

Patmasari. Hubungan Peran Dosen Pembimbing Akademik dengan Prestasi Mahasiswa Tingkat II Program Studi D-III Kebidanan Hafsyah Medan 2013/2014. Kebidanan. 2014;10:40-1.

Yeni M. Hubungan Peran Dosen Pembimbing Akademik Dengan Prestasi Belajar Mahasiswa Semester VI di Akademi Kebidanan Pemkab Langkat Tahun 2010/2011. Kesehatan. 2011;9. 